Article

\title{
Improving the Net Benefits from Tourism for People Living in Remote Northern Australia
}

\section{Romy Greiner}

School for Environmental Research, Institute of Advanced Studies, Charles Darwin University, Darwin, NT 0909, Australia; E-Mail: romy.greiner@cdu.edu.au; Tel.: +61-4-1824-2156.

Received: 6 June 2010; in revised form: 27 June 2010 / Accepted: 29 June 2010 /

Published: 15 July 2010

\begin{abstract}
Tourism can be an important source of livelihoods at a destination level. Yet, while there are economic benefits associated with more tourists, there can also be costs to destinations in the form of negative environmental and social impacts. This paper illustrates tourism-related dilemmas for two remote regions within Australia's tropical savannas where increasing visitor numbers are straining not only the very environmental assets that attract tourist, but also the host communities. The paper draws on research conducted under the auspices of the Tropical Savannas Management Cooperative Research Centre. Tourism impacts on the regions are described and, where possible, quantified and distributional effects discussed. Evidence is provided that host populations in the remote of Australia's tropical savannas are willing to trade off environmental and social costs for economic benefits, but that this situation may not be ecologically sustainable. The regions are parts of much larger destinations and consequently peripheral to their concerns. The onus for sustainable tourism and regional development strategies therefore falls on local decision makers. The research presented here provides a framework for local decision makers and stakeholders to ask questions, collect relevant data, and proceed with informed debates and choices.
\end{abstract}

Keywords: Kimberley; Gulf of Carpentaria; tropical savannas; nature-based tourism; host populations; indigenous participation 


\section{Introduction}

Tourism growth is often considered an integral element of economic development strategies for remote countries and rural and remote areas within countries, particularly where once prevalent primary industries are in decline. It is generally promoted as a source of employment, revenue, additional tax receipts, foreign exchange benefits and enhanced community infrastructure [1] and can act as a tool for sustainable development in transition economies [2]. For people living in remote and peripheral regions with few industry options, tourism can provide a vital contribution to livelihoods [3]. For example for central-west Queensland, a remote region within Australia's vast outback and part of its tropical savanna landscapes, tourism has been 'transformational' for the regional economy, facilitating the transition from a declining predominantly primary industry economy to a service economy [4]. Like many remote regions elsewhere, Australia's tropical savannas offer an essentially nature-based tourist product [5]. Vast landscapes offer drive-through, four-wheel driving, bushwalking and birdwatching experiences. Extensive coastlines, rivers and waterholes support recreational fishing. Indigenous communities provide cultural experiences. Tropical savannas therefore retain aesthetic amenity and wilderness qualities that no longer exist in non-peripheral areas [6].

While economic benefits, including increased business activity and employment, clearly arise from an expanding tourism industry in remote areas, there can be social and environmental costs - particularly (i) because tourism is nature-based and therefore dependent on and a major user of natural resources and biodiversity [7] and (ii) when tourism collides with the values and aspirations of host communities. In north Australia's remote regions the proportion of indigenous people tends to be high among the resident population [8] and consequently cultural impacts of tourism are also of concern [9].

Developing nature-based tourism in remote areas such as the tropical savannas is a "difficult balancing act between achieving regional development objectives and retaining high levels of naturalness" ([10], p. 7). Maintaining natural attractions and environmental assets is critical to the sustainability of nature-based tourist destinations as, by definition, these form the basis for leisure travel undertaken predominantly for the purpose of enjoying natural attractions and engaging in a variety of outdoor activities. The challenge of trading off between conflicting objectives and different stakeholder interests in remote areas in particular is heightened by a general lack of data [11], and data which are often incomparable, inconsistent or not credible [12].

This paper consolidates tourism research carried out under the umbrella of Australia's Tropical Savannas Management Cooperative Research Centre (TSM-CRC) during 2003-2005. It expands on and re-interprets the results from several projects [13-16] and seeks to contribute to the existing body of knowledge in three ways:

(i) It adds to the body of evidence of social and environmental impact of tourism on host communities and remote destinations. It provides empirical evidence to inform tourism planning and management in each of the regions.

(ii) By looking at remote area tourism through a host community lens, it demonstrates the relevance of the concept of net social benefit-i.e., simultaneously considering the social, economic and environmental impacts at the destination scale. 
(iii) It helps define minimum data requirements to ensure tourism planning and management in remote nature-based regions is consistent with principles of ecologically sustainable development.

This paper adopts a host community lens to ask the question of what benefits and costs of tourism accrue at the destination level, where tourists enjoy and use the natural attractions and existing infrastructure and services. 'Destination' is defined in this context as a cohesive geographical area which offers a specific set of natural attractions within a landscape and attracts visitors in its own right. The concept of 'net social benefit' is used to (i) encapsulate economic, social and environmental benefits and costs, and (ii) ask whether benefits outweigh costs overall. The definition is deliberately broader than a purely market-value based conceptualisation of net social benefit [17] so as to include non-monetary values and allow trade-offs across economic, social and environmental domains. Simultaneously considering the economic, social and environmental dimensions of tourism (e.g., [18]) also enables an interpretation of the research within the context of Ecologically Sustainable Development (ESD).

In 1992, the Council of Australian Governments endorsed the National Strategy for ESD, with ESD being defined as “using, conserving and enhancing the community's resources so that ecological processes, on which life depends, are maintained, and the total quality of life, now and in the future, can be increased" [19]. Key principles of ESD are the integrated consideration of wider economic, social and environmental implications of decisions and actions, and the adoption of a long-term view.

Arguably, if regional tourism development complies with ESD principles, then increasing tourism activity will provide economic benefits without causing social and environmental costs. Tourism, then, is being planned and managed in a manner and at a scale that contributes to host population livelihoods into the future without degrading the natural and social environment [20]. There is evidence to suggest that tourism growth in at least some areas within the tropical savannas may not be consistent with ESD principles: Increasing visitor numbers are reported to be straining resources, the environment, infrastructure, local services and remote communities themselves [4]. Yet, the explicit objective of more centrally located stakeholders, including tourist organisations and governments, is often to grow tourist numbers in remote areas based on the assumption that more tourists are better. For example, in 2005 the Savannah Way promotion commenced with the explicit aim of increasing drive tourism through the tropical savannas [21]. In 2010, the Kimberley was afforded 'National Landscapes' status with the expressed purpose of celebrating its environmental assets and promoting it as a tourist destination internationally [22]. The extent to which such initiatives consider values and aspirations of host populations is questionable. ESD sensitive planning and management requires the ability to anticipate, monitor, and control impacts which have the potential to threaten the social foundations and natural assets which support both, the quality of life for residents and visitor attractions.

\section{Net Social Benefit from Tourism for Remote Tourist Destinations}

Host populations need to 'reconcile economic gain and benefits with the costs of living with strangers' ([23], p. 55). Such a reconciliation or integration is at the heart of the question of 'net social benefit' and requires data and an understanding of tourism benefits and costs, as well as relevant factors and relationships. Such knowledge is particularly pertinent in a remote destination context, 
where even relatively small numbers of tourists can have large impacts [24]. Integrating economic, social and environmental dimensions is best facilitated by adopting a systems view of tourism. Tourism system models are helpful because of their explanatory power [25]. They can (i) illustrate various facets of tourism, (ii) explore interdependencies of major components and internal feedback relationships [26], (iii) investigate external influence factors and (iv) demonstrate the scope of influence of various decision makers. Many systems models of tourism have been developed, most of which take a tourist demand perspective, often with the intention of improving the competitiveness of a destination and increasing tourist numbers. Many of these models have their philosophical roots in the work by Leiper [27], Gunn [28] and Smith [29].

Few models, however, concern themselves with the social and environmental interactions of tourists with a destination. Butler's destination life-cycle theory [30] offers important qualitative insights into the evolution and development of tourist destinations and potential social and environmental ramifications [31]. The research presented here adopts the principal tourism system relationships that underpin the destination life cycle model. Figure 1 depicts a conceptual remote region tourism systems model, including decision and impact variables, and explains key relationships and causalities. It conceives natural resources as the key elements of the tourist product offered by tropical savanna destinations. The environmental assets are supplemented by man-made attractions and tourist infrastructure, and communicated to potential customers through marketing and promotion [31], by marketing bodies but also through 'word-of-mouth' promotion (e.g., [32]). The model takes a positive view - as opposed to a carrying-capacity based view — and asserts that by maintaining its natural assets and strategically supplementing and marking those, remote destinations can influence the number and types of visitors. This, in turn will determine the economic, social and environmental footprint of tourism and the net benefit for the host community.

Figure 1. Conceptual model of tourism development and social net benefit.

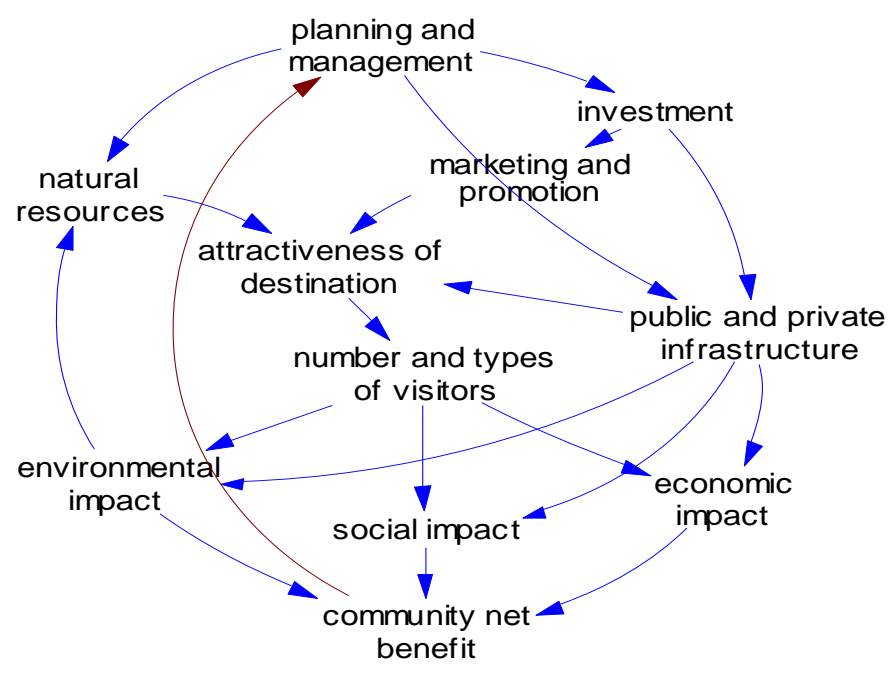

One way to capture tourism impact is by measuring tourist activity, economically and otherwise. Another way is to elicit the impact of the activity on the host region and its population, as tourism 
impact at its core is about tourism community relationships and host perceptions [33]. The research presented here pursues both avenues.

\section{The Gulf of Carpentaria and Northern Kimberley Regions}

The Gulf of Carpentaria and northern Kimberley regions are located within the tropical savannas landscapes of northern Australia. Figure 2 depicts the regions as defined in the context of the TSM-CRC research. Both regions cover land areas of several ten thousand square kilometers. They are typical of the tropical savannas, which are vast and sparsely populated, dominated by tree, scrub and grass savannas. Since European settlement, the primary land use in Australia's tropical savannas has been extensive beef and, to a lesser extent, sheep production [34]. The livestock industry is generally based upon private enterprises, with farms ranging in size from a few square kilometres to approximately $24,000 \mathrm{~km}^{2}$ and carrying up to 65,000 head of cattle [35]. Symptomatic of the "multifunctional transition" of Australia's rangelands ([36], p. 142), tourism is playing an increasingly important economic role in remote regions. In terms of proportion of workforce employed, tourism now surpasses agriculture in a majority of the statistical divisions which geographically overlap the tropical savannas ([37], p. 48). Employment in the 'accommodation' sector alone exceeds employment in 'grains and sheep/beef cattle farming' in central and northern Queensland and in the Northern Territory [38].

Figure 2. Location map of Gulf of Carpentaria and northern Kimberley regions.

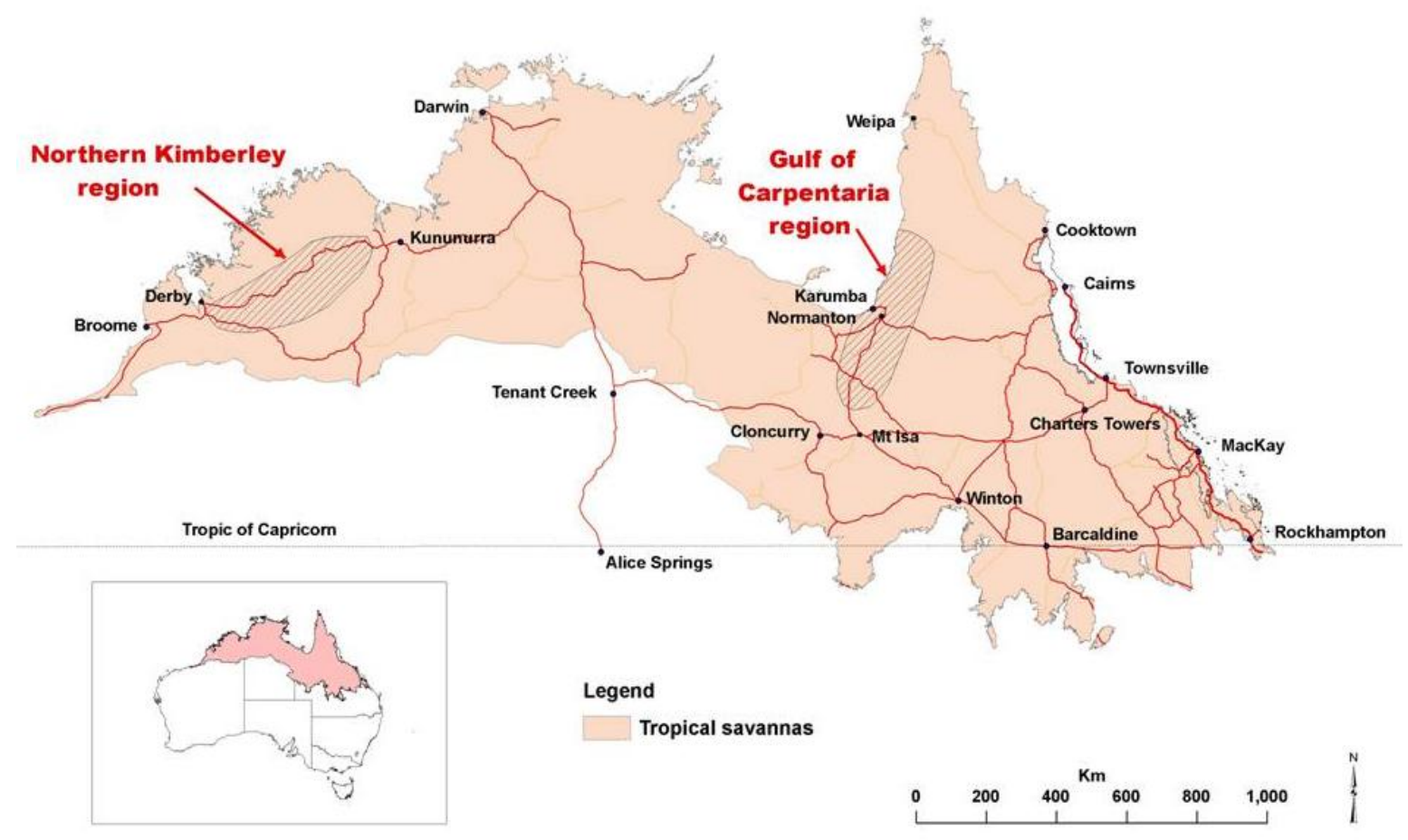

The tropical savannas are remote from all major population centres in Australia, and the Gulf of Carpentaria and northern Kimberley regions are particularly remote. The distance to the nearest regional centre with a population $>100,000$ inhabitants is more than 700 and 900 kilometres, respectively (Cairns, Darwin), and the regions lie more than 2,000 kilometres north of the respective 
state capital cities (Brisbane, Perth). In addition to being geographically isolated they are also distant from core spheres of activity and places of decision making. In a tourism sense, both regions form part of larger tourism destinations, Outback Queensland and the Australia's North West respectively, and lie outside the mainstream tourist areas. They therefore meet the criteria of peripherality [39]. Table 1 provides key information on both regions.

Table 1. Key regional and tourism descriptors of Gulf of Carpentaria and northern Kimberley regions (Sources: [13-16,40,41]; Note: (1) data for Carpentaria Shire, with focus on Karumba and Normanton, (2) data for eastern part of Shire of Derby-West Kimberley only).

\begin{tabular}{ll}
\hline Descriptors & Gulf of Carpentaria ${ }^{(1)}$ \\
\hline Area $\left(\mathrm{km}^{2}\right)$ & 69,000 \\
Resident population (persons) & 2100 \\
Percentage Indigenous population & $38 \%$ \\
Part of larger tourist destination & "Outback Queensland" \\
Key attractions $[15,16]$ & Coast: recreational fishing; mild winter \\
& climate (for people from southern \\
& states); sealed road access; permanent \\
& wetlands, bird watching
\end{tabular}

Tourist infrastructure and services provided [14-16]

Indigenous participation in tourism industry [13-15]

Number of tourists per year $[15,16]$

Type of tourists - as proportion of survey respondents $[15,16]$

Origin of tourists - as proportion of survey respondents $[15,16]$

Mean duration of stay in region (days) $[15,16]$

Key community concerns about tourism [13-15]
27 tourist businesses, including: 15 accommodation providers, 3 service stations, 4 shops, 3 charter fishing operators, 2 scenic water tour operators $2 \%$ of indigenous people employed in tourist-related jobs; unskilled labour

$\approx 15,000$ overnight visitors staying in commercial accommodation places Independent; self-drive (98\%), mostly own four-wheel drive with caravan (and boat)

International $8 \%$

Interstate 42 ; mostly return visitors Intrastate $50 \%$; mostly return visitors 20 (73 days for retirees, 9.1 days for families)

Sustainability of fish species targeted by tourist (and resident) anglers; shortage of drinking water during dry season

Northern Kimberley $^{(2)}$
$\approx 80,000$
$\approx 2,000$
$\approx 50 \%$

"Australia's North West"

Gibb River Road: iconic road, largely un-sealed: four-wheel-drive experience; landscape features, including gorges, waterfalls and landscape in general; notion of wilderness and remoteness; bird watching

3 service stations with basic shopping

4 pastoral properties offering basic cabin-style accommodation and camping several camping grounds in national parks Few jobs; unskilled labour; own one service station; service contract with one tour operator; some arts sales $\approx 16,000$ independent travelers; number of clients on tours is unknown

Independent (68\% own car and $32 \%$ rental car); tour buses (35 tour operators)

International $25 \%$

Interstate $60 \%$

Intrastate (Western Australia) 15\%

8.0

Weeds, illegal camping, fires being caused, faeces, littering, lack of planning, lack of indigenous engagement and participation, traffic causing corrugation of Gibb River Road 
The two regions are climatically similar, characterised by tropical climate with monsoonal summers, when high temperatures and humidity make for unpleasant outdoors conditions and roads are often impassable after rain. The dry warm winter months are when tourism activity is at its peak. Despite their similarities, the two regions feature distinct tourist attractions and serve to illustrate different dilemmas for remote host communities that arise from unplanned and unmanaged tourism and tourism growth.

Viewed through a destination life cycle lens, the northern Kimberley region would be at the exploration/early growth stage of development [42], and has 'undeveloped recreation resources', where the physical attributes of land, water and vegetation are the key features of the tourist product and are largely untouched ([43], p. 98). There are some national parks and "the legendary Gibb River Road, a $660 \mathrm{~km}$ dirt track right through the wild heart of the Kimberley" [44]. The road provides access to pastoral properties and various nature reserves and national parks. In comparison, the Gulf of Carpentaria region is a mature recreational-fishing based tourism destination. The small coastal town of Karumba in particular bears the title of "the tourist capital of the Gulf" and is "home to Australia's biggest recreational grunter fishery" [45].

Demographically, both regions have proportionally large indigenous populations. When the research was conducted, indigenous tourism, in the sense of "tourism activity in which indigenous people are directly involved either through control and/or by having their culture serve as the essence of the attraction" ([46], p. 9) was rare in both cases. In the Gulf of Carpentaria region an indigenous theme was completely absent. In the northern Kimberley region there was some indigenous involvement through ownership and leasing out of a roadhouse, arrangements with an indigenous tour operator to use indigenous owned land, and sales or arts and crafts [14].

In terms of tourism impact on the host community, even small numbers of tourists can have a large local impact if tourist numbers are large relative to the population base [24]. Carpentaria Shire had approximately 15,000 tourists staying in commercial premises during 2003/04 [15]. Given the long average duration of stay, this equated to approximately 280,000 visitor nights and translated to a significant increase in demand for public infrastructure and services during the tourist season, including for water, rubbish removal, health services and others [15]. Different types of visitors had distinct spending and activity patterns [15,24].

\section{Method}

The host perspective pursued by this research was gained by extensive consultation with regional stakeholders and the resident population during the course of the research, during the scoping and data collection phases. Tourist surveys were also conducted. Tables 2 and 3 provide a summary of the survey methods employed in the Gulf of Carpentaria and northern Kimberley regions, respectively. Social survey was the method of choice for investigating tourism impact in both destinations. Survey method design applied the Dillman principles [47]. 
Table 2. Surveys conducted in the Gulf of Carpentaria region.

\begin{tabular}{|c|c|c|c|c|}
\hline & Visitor survey [15] & Resident survey [15] & Business survey [15] & Consumer survey [15] \\
\hline Target population & $\begin{array}{l}\text { Tourists } \\
\text { (visiting parties) }\end{array}$ & Residents & Business managers & $\begin{array}{l}\text { Shoppers } \\
\text { (tourist and residents) }\end{array}$ \\
\hline Scope & $\begin{array}{l}\text { Socio-economic profile, } \\
\text { expectations, activities } \\
\text { with specific emphasis on } \\
\text { fishing, spending, } \\
\text { preferences }\end{array}$ & $\begin{array}{l}\text { Perceived economic, } \\
\text { social and environmental } \\
\text { benefits \& costs } \\
\text { of tourism }\end{array}$ & $\begin{array}{l}\text { Employment, business } \\
\text { income and expenses, } \\
\text { location of transactions }\end{array}$ & Expenditure on groceries \\
\hline Data collection & Face-to-face & Face-to-face & Face-to-face & Face-to-face \\
\hline $\begin{array}{l}\text { Stratification } \\
\text { method }\end{array}$ & $\begin{array}{l}\text { Tourist seasonality, } \\
\text { location, accommodation } \\
\text { type }\end{array}$ & $\begin{array}{l}\text { Location, ethnicity, } \\
\text { gender, age, profession }\end{array}$ & $\begin{array}{l}\text { Attempt at capturing } \\
\text { total population }\end{array}$ & Shops \\
\hline When conducted & $\begin{array}{l}\text { July 2002, Sept 2002, } \\
\text { Feb 2003, April } 2003\end{array}$ & Nov 2003 & Sept 2003 & Sept 2003 \\
\hline Sample size & $\begin{array}{l}510 \text { travel parties } \\
(1,400 \text { tourists })\end{array}$ & 87 residents & 24 businesses & $\begin{array}{l}128 \text { total } \\
\text { ( } 71 \text { residents, } 57 \text { tourists) }\end{array}$ \\
\hline
\end{tabular}

Table 3. Surveys conducted in the northern Kimberley region.

\begin{tabular}{|c|c|c|c|c|}
\hline & Tourist survey [16] & $\begin{array}{l}\text { Landholder } \\
\text { survey [14] }\end{array}$ & $\begin{array}{l}\text { Tour operator } \\
\text { survey }[14]\end{array}$ & $\begin{array}{l}\text { Expert interviews } \\
{[13,14,16]}\end{array}$ \\
\hline Target population & $\begin{array}{l}\text { Tourists } \\
\text { (Independent travellers) }\end{array}$ & $\begin{array}{l}\text { Land owners and } \\
\text { managers adjoining the } \\
\text { Gibb River Road }\end{array}$ & $\begin{array}{l}\text { Tour operators that } \\
\text { conduct tours on the } \\
\text { Gibb River Road }\end{array}$ & $\begin{array}{l}\text { Experts and key } \\
\text { stakeholders }\end{array}$ \\
\hline Scope & $\begin{array}{l}\text { Socio-economic profile, } \\
\text { expectations, activities, } \\
\text { spending, preferences }\end{array}$ & $\begin{array}{l}\text { Involvement in } \\
\text { tourism; perceived } \\
\text { impacts }\end{array}$ & $\begin{array}{l}\text { Extent of usage; } \\
\text { attractions; relationships } \\
\text { with northern Kimberley } \\
\text { businesses }\end{array}$ & $\begin{array}{l}\text { Perceived economic, } \\
\text { social and environmental } \\
\text { benefits \& costs of } \\
\text { tourism }\end{array}$ \\
\hline Data collection & $\begin{array}{l}\text { Distribution at tourist } \\
\text { information places, petrol } \\
\text { stations; mail reply }\end{array}$ & Face-to-face & Email mail-out \& return & Face-to-face \\
\hline $\begin{array}{l}\text { Stratification } \\
\text { method }\end{array}$ & n/a: Snapshot approach & $\begin{array}{l}\text { All landholders } \\
\text { approached }\end{array}$ & $\begin{array}{l}\text { All tour operators } \\
\text { approached }\end{array}$ & $\begin{array}{l}\text { Attempt at ensuring } \\
\text { broad expert input }\end{array}$ \\
\hline When conducted & July-Nov 2004 & May 2004 & May-Sept 2004 & Sept 2003-Nov 2004 \\
\hline Sample size & $\begin{array}{l}202 \text { travel parties } \\
\text { (499 tourists) }\end{array}$ & $\begin{array}{l}18 \text { landholders } \\
\text { (response rate } 100 \% \text { ) }\end{array}$ & $\begin{array}{l}8 \text { operators } \\
\text { (response rate } 23 \% \text { ) }\end{array}$ & $\mathrm{n} / \mathrm{a}$ \\
\hline
\end{tabular}

Of particular interest in the context of this paper is the survey of residents, the results of which are used as lens for assessing net social benefit of tourism. The resident survey was a face-to-face survey conducted of local residents in the Gulf of Carpentaria region to determine host community perceptions of tourism impacts on the region. Resident perception surveys have been undertaken elsewhere [48-50] and this research adopted a standard 5-point Likert-type scale rating approach while tailoring item selection to the destination. Perceptions of impacts, whether positive or negative, were triangulated, to the extent possible, with other sources of data obtained in the course of the research. 
Care was taken in method design to avoid intrinsic bias of results towards preconceptions [51,52]. The survey was pre-tested with tourist experts in the region. Pretest results were not included in the survey results.

The objective of the Carpentaria resident survey was to assist the explanatory elements of the research rather than to establish absolute impact ratings. Sampling was therefore not strictly random as residents in professional roles were specifically sought out, including key personnel in the council office, schools and TAFE, hospitals, police, indigenous organisations and banks. Professionals made up $26 \%$ of the sample of 73 respondents. While the sample did not provide a statistically true representation of the total population in Carpentaria Shire, it did represent a diverse cross-section of the community. Of respondents, 59\% of respondents were from Normanton and $41 \%$ from Karumba; $23 \%$ were indigenous; $58 \%$ were female; $37 \%$ had lived in the region for less than 5 years and $30 \%$ for more than 25 years.

Similar to other studies (e.g., [53]), respondents were asked to rate, on a 5-point Likert-type scale, their perception of impact of tourism on a series of attributes. Of attributes, eight referred to economic facets, including tourism workforce participation. There were 14 attributes relating to social and lifestyle facets and seven environmental attributes, all of which had been developed during project scoping. Following the ratings, respondents were asked whether they considered tourism to be positive or negative for the region on balance. This question allowed respondents to consolidate the various benefits and costs associated with tourism and to indicate their private view of tourism net social benefit. Post hoc comparisons were conducted based on locality of respondents and other socio-demographic variables. The Tukey HSD test for unequal sample sizes was employed. The 5\% level was chosen to denote statistical significance.

The methodological approach to assessing tourism impacts and net benefit in the northern Kimberley region was based on literature review and qualitative interviews of local residents.

\section{Tourism Impacts}

\subsection{Gulf of Carpentaria Region}

Figure 3 shows the mean values of perceived impact for each attribute across the sample, painting a picture of largely positive economic and social, but distinctly negative environmental tourism impacts.

Respondents perceived highly positive effects in terms of local employment (despite some competition from tourists for jobs during peak season) and business activity, as well as government spending in the region. Perceptions are well aligned with the quantifiable economic impacts of tourism. For 2003, tourist expenditure in Carpentaria Shire was estimated to be $\$ 11.3$ million, value added $\$ 14.1$ million and employment in tourism related industries 180 persons, equivalent to $15 \%$ of the workforce in Carpentaria Shire and therefore similar in size to employment in the 'agriculture, forestry and fishing' sector [15]. 
Figure 3. Host community perception of tourism impacts in Carpentaria Shire Source: adapted from [15]; unweighted mean values and standard deviations; $\mathrm{n}=73$; "highly negative" $=-2$ and "highly positive" $=+2$; items sorted by mean value within categories.

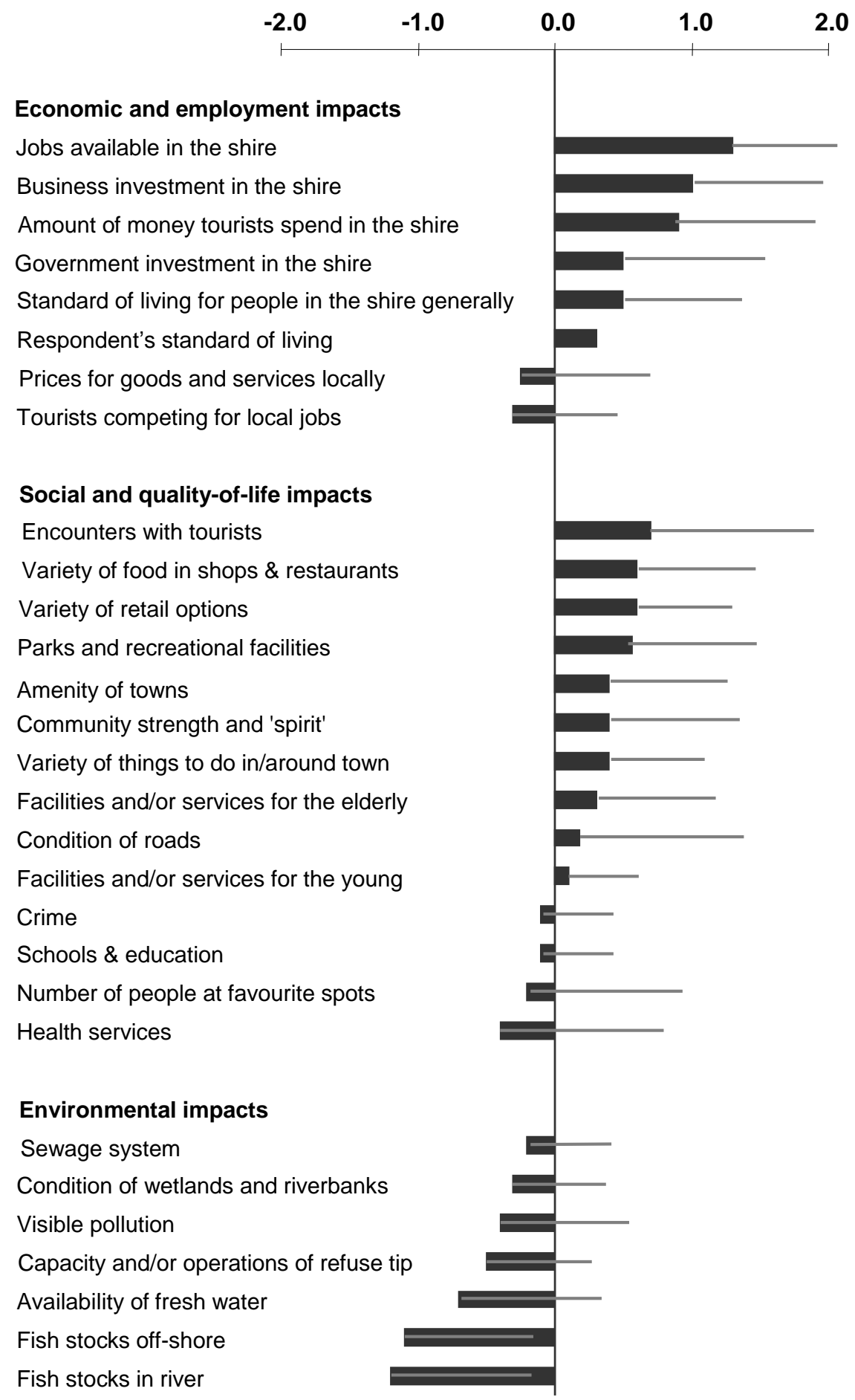

Respondents rated tourism as highly detrimental to fish stocks in rivers and estuaries. While there are no fish stock assessments available for the Karumba area and the Norman river, additional research has been conducted into the consumptive dimensions on recreational fishing by tourists [54]. Based on a survey of 1,050 recreational fishers in Karumba during the March-September 2006 tourist season, 
recreational tourist recreational harvest was between 197-234 tonnes with about 250,000-307,000 specimens caught and approximately 94,000-112,000 kept [55]. Grunter (Pomadasys kaakan) accounted for about half the harvest (100-118 tonnes), followed by blue salmon (Eleutheronema tetradactylum) (32-38 tonnes). In comparison, local residents' recreational harvest was estimated between 1.7 and 3.7 tonnes for the whole of 2006 [54]. For some species, total recreational take was small compared to commercial harvest (e.g., barramundi (Lates calcarifer), king salmon (Polydactylus macrochir)). For other species however, recreational take significantly contributed to total harvest in the Gulf of Carpentaria waters, and in some instances exceeded commercial harvest (in particular for grunter, Spanish mackerel (Scomberomorus commerson) and blue salmon) [55]. This level of recreational harvest supports residents' assessment of a large negative impact of tourism on fish stocks and resulting concern about the sustainability of local fisheries. The concern of respondents regarding impact of tourism on freshwater supplies was also supported, with the local council imposing water restrictions during the dry season [15].

Tourists were perceived to have a negative impact on health services in the region. This is because (i) during peak tourist season the population of the region virtually doubles and (ii) mostly retiree (i.e., elderly) tourists have a high demand for health infrastructure and services. Tourists were also perceived to generate congestion at places popular with local residents. However, most respondents rated social interactions with visitors as positive. There was also a general view that tourism had a positive impact on the product range offered by local retail businesses and service delivery (e.g., maintenance of public areas and parks) by the shire council.

To glean how the impacts of tourism, benefits and costs, were distributed across the host population, respondents were classified into groups according to location in Shire (Normanton-Karumba), indigenous status, (indigenous - non-indigenous), gender, age, length of residency in the Shire and occupation. The data were tested for statistically significant differences between groups. Post hoc analysis revealed that perceptions of tourist impact were largely congruent across sections of the host community. For example, testing for possible gender differences yielded no result. However, some significant differences were found based on place of residence and indigenous status (Table 4).

Non-indigenous Normanton residents generally perceived larger economic benefits from tourism than Karumba residents, while Karumba residents attributed a significantly larger positive impact from tourism-related business activity. Non-indigenous respondents rated the impact of tourism on their standard of living as generally positive, while the rating was negative for indigenous respondents, who perceived a significant negative impact on the price of goods and services in the region. The generally lower economic benefit ratings provided by indigenous respondents can be explained by the low level of economic participation by indigenous people in the Gulf of Carpentaria region in tourism, who are consequently missing out on the economic opportunities that tourism provides. In 2003, $15 \%$ of the regional workforce was employed in tourism, however only two percent of the indigenous workforce was employed in the industry. At the same time, indigenous people were disproportionately affected by high retail prices because of generally lower individual and household incomes combined with limited transportation and therefore ability to do bulk shopping in large regional centres such as Cairns and Mt Isa [15]. 
Table 4. Tourism impact rating, mean values, by indigenous status and location.

\begin{tabular}{|c|c|c|c|}
\hline & \multirow{2}{*}{$\begin{array}{l}\text { Indigenous } \\
\text { Normanton }\end{array}$} & \multicolumn{2}{|c|}{ Non-indigenous } \\
\hline & & Normanton & Karumba \\
\hline \multicolumn{4}{|l|}{ Economic and employment impacts } \\
\hline Jobs available in the Shire & 0.76 & 1.52 & 1.29 \\
\hline Tourists competing for local jobs & -0.50 & -0.33 & -0.27 \\
\hline Business investment in the Shire (1) & $0.87^{\mathrm{a}, \mathrm{b}}$ & $0.63^{\mathrm{a}}$ & $1.31^{\mathrm{b}}$ \\
\hline Government investment in the Shire & 0.50 & 0.65 & 0.40 \\
\hline Amount of money people spend in the Shire & 0.53 & 1.12 & 0.97 \\
\hline Prices of goods and services locally (1) & $-0.76^{\mathrm{a}}$ & $-0.07^{b}$ & $-0.10^{b}$ \\
\hline Your standard of living & -0.13 & 0.48 & 0.24 \\
\hline $\begin{array}{l}\text { Standard of living for people in the Shire } \\
\text { generally }\end{array}$ & 0.31 & 0.48 & 0.65 \\
\hline Aggregate economic impact (2) & 0.20 & 0.56 & 0.56 \\
\hline \multicolumn{4}{|l|}{ Social and quality-of-life impacts } \\
\hline Health services & -0.50 & -0.19 & -0.54 \\
\hline Condition of roads & -0.18 & 0.07 & 0.48 \\
\hline Schools \& education & 0.25 & -0.23 & -0.07 \\
\hline Facilities and/or services for the elderly & 0.08 & 0.68 & 0.12 \\
\hline Facilities and/or services for the young & -0.07 & 0.15 & 0.11 \\
\hline Parks and recreational facilities & 0.47 & 0.74 & 0.45 \\
\hline Community strength and 'spirit' & 0.06 & 0.44 & 0.43 \\
\hline Crime & -0.36 & 0.00 & -0.14 \\
\hline Variety of things to do in/around town & 0.19 & 0.44 & 0.55 \\
\hline Variety of food in shops \& restaurants & 0.38 & 0.54 & 0.79 \\
\hline Variety of retail options & 0.56 & 0.74 & 0.41 \\
\hline Encounters with tourists & 0.29 & 0.69 & 0.86 \\
\hline Number of people at favourite spots (1) & $0.00^{\mathrm{a}, \mathrm{b}}$ & $0.20^{\mathrm{a}}$ & $-0.62^{b}$ \\
\hline Amenity of towns & 0.24 & 0.65 & 0.29 \\
\hline Aggregate social impact (2) & 0.10 & 0.35 & 0.22 \\
\hline \multicolumn{4}{|l|}{ Environmental impacts } \\
\hline Availability of fresh water (1) & $-0.60^{\mathrm{a}, \mathrm{b}}$ & $-0.26^{\mathrm{a}}$ & $-1.10^{\mathrm{b}}$ \\
\hline Visible pollution (eg. roadsides) & -0.13 & -0.58 & -0.50 \\
\hline Capacity and/or operations of refuse tip (1) & $-0.07^{\mathrm{a}}$ & $-0.32^{\mathrm{a}, \mathrm{b}}$ & $-0.79^{b}$ \\
\hline Sewage system & 0.08 & -0.21 & -0.40 \\
\hline Fish stocks in river (1) & $-0.75^{a}$ & $-1.00^{\mathrm{a}}$ & $-1.63^{b}$ \\
\hline Fish stocks off-shore & -0.71 & -1.05 & -1.48 \\
\hline Condition of wetlands and riverbanks & -0.50 & -0.09 & -0.38 \\
\hline Aggregate environmental impact (2) & -0.38 & -0.50 & -0.90 \\
\hline Tourism net benefit rating (3) & 1.24 & 1.12 & 1.28 \\
\hline
\end{tabular}

Source: [15]; $\mathrm{n}=73$; Note: There were no indigenous residents living in Karumba at the time of the survey; (1) superscripts provided for means of those attributes where significant differences between respondent groups were detected. Different superscripts indicate statistically significant group means (5\%): Kruskal-Wallis test. (2) unweighted means are provided for each category of attributes for respondent groups as a way of gauging magnitude of impact perceived by category; (3) tourism net benefit rating: ' 1 ' $=$ benefits > costs; ' 2 ' $=$ costs > benefits 
Across economic indicators, non-indigenous respondents rated the economic benefit of tourism higher than indigenous respondents. This result is consistent with the literature, whereby perceptions of positive impact are related to personal benefits from tourism [27].

Karumba-based respondents were generally more concerned about the environmental impacts of tourism and specifically perceived larger negative impact of tourists on fish stocks, drinking water availability and operations of the refuse tip. They were also more sensitive to having to share their favourite recreational areas with the visitors. This result is consistent with the literature in that people with personal benefits from tourism are also more likely than others to report negative impacts [27].

Asked whether they thought that benefits to the region from tourism outweighed negative impacts, $78 \%$ of respondents answered in the affirmative. There were no statistically significant differences based on gender, locality and indigenous status of respondents. This result indicates that (i) the host community is willing to trade off environmental impacts arising from tourist consumptive behaviour for economic and social gain, and (ii) even segments of the host community who may not directly benefit directly are supportive of tourism.

\subsection{Northern Kimberley Region}

Landholders along the Gibb River Road are the people within the northern Kimberley community who most directly interact with the tourist industry. After all, many of them are not only agricultural producers (graziers) but also the principal providers of tourist infrastructure and services. Semi-structured questionnaires of landholders (see Table 3) revealed the following environmental and social tourism impacts [13]:

- Introduction and spread of weeds, through unintentional translocation by vehicles (tyres and car body), tourist boots and clothing, swags and tents

- Litter and (unburied) faeces left by tourists, which constitute a management problem for landholders, an eyesore to residents and the travelling public alike, and a public health hazard

- Wildfires caused by camp fires (in uncontrolled areas) or discarded cigarette butts

- Degeneration (corrugation) of the Gibb River Road due to volume of tourist traffic, resulting in high wear and tear of vehicles and higher commercial transport costs

- Tourist traffic (travel behaviour) resulting in unsafe road conditions

Results of a survey of independent travelers (see Table 3) confirmed some of the tourist behaviours causing environmental impacts. A majority of survey respondents $(78 \%)$ reported going to the toilet 'in the bush' and 30\% reported that they had camped outside licensed camping areas [16,42]. Very few respondents reported that they had littered. Extrapolating the survey results will likely lead to an underestimate of the frequency of these behaviours across all tourists due to strategic underreporting by respondents and non-participation in the survey by tourists with high frequency of offending behaviours.

Negative externalities from tourism in the northern Kimberley have also been reported to arise from increasing and uncontrolled boating tourism along the Kimberley shoreline, where tourists traveling by yachts, cruise and charter boats regularly come ashore. They cause similar environmental impacts as along the Gibb River Road and frequently trespass on indigenous sacred sites [56,57]. 
The community (landholders and indigenous communities) adjoining the Gibb River Road articulated their concern with these impacts as well as other tourism-related issues northern Kimberley including ([13,24], Table 3):

- Lack of infrastructure for visitors in the face of increasing tourist numbers

- Poor management of the region in general and of tourism specifically

- Lack of indigenous involvement in tourism

- Uncertain regulatory framework governing the commercial opportunities of landholders in relation to tourism

These views need to be interpreted on the basis of the specific nature of infrastructure and service provision in the northern Kimberley. With the exception of two privately run petrol stations/shops and basic camping facilities in several national parks/nature reserves it is the landholders, predominantly graziers, who are providing infrastructure in the form of motel-style and other accommodation, meals, fuel and other supplies to tourists [13,14]. All non-indigenous landholders in the area lease their land from the Crown and many leases are approaching renewal, which causes uncertainty regarding the ability of landholders to continue their pastoral and tourist operations into the future. While Western Australian lease conditions stipulate that the priority enterprise of a grazing lease must be grazing, diversification permits increasingly allow lessees to expand commercial tourism ventures and undertake conservation on their land [14]. This diversification provides an important strategy for maximizing business resilience [58].

\section{Discussion and Conclusions}

The quality, diversity, abundance and accessibility of environmental assets in the tropical savannas provide the impetus for tourists to visit remote north Australian regions. The notions of remoteness and wilderness are key elements of their tourist products. Peripherality is thus an asset [10]. Host populations are generally welcoming of tourists and appreciate the income and employment benefits generated by them. Existing small businesses have diversified their operations and new businesses have emerged to provide infrastructure and services. Increasing tourism demand has thus allowed many destination regions within the tropical savannas to diversify their economies.

As the two regions which are featured in this paper illustrate, there has been a price to pay for tourism, particularly in terms of environmental impacts. In the Gulf of Carpentaria, in particular, recreational fishing-based tourism is highly consumptive of natural resources. Tourists take fish in numbers that rival and, for some species, even exceed the harvest of commercial fisheries. While individuals may well stay within legal possession limits, the aggregate and cumulative impact of this level of resource extraction is as yet unknown [55]. Similar environmental issues either exist or are emerging in other parts of the Tropical Savannas, in particular the Nhulunbuy and Mc Arthur River regions in the Northern Territory and the Burketown region in Queensland. The reverse problem exists in the northern Kimberley, where tourists leave in their wake weeds, excrement and fires. From tourist accounts it is questionable, whether the rubbish problem is indeed associated with tourism or more attributable to the residential population [16].

There are also social costs or inconveniences involved for host populations. These can take benign forms such as having to share favourite recreational areas and incurring inconveniences associated 
with tourist traffic on country roads. However, the socially most disadvantaged sections of the host population, specifically the indigenous population, are particularly affected by shops inflating prices during the tourist season and the single ambulance in the Gulf of Carpentaria region being tied up with emergencies of a majority elderly tourist population [15]. There are also disparities in the distribution of economic benefits from tourism between the indigenous and non-indigenous sections of host populations, with very limited direct involvement of the indigenous population in tourism. Seasonal tourist workers even compete for (unskilled) jobs during the tourist season. This is an indicator of inequalities in the distribution of net social benefits from tourism within regional communities. On the other hand, this situation points to an untapped potential for culturally specific tourist experiences. Some indigenous communities within the tropical savannas have successfully tapped this potential, for example the Jawoyn people at Nitmiluk [59]). However, pathways to and extent of indigenous participation in tourism will differ between indigenous peoples depending on their particular circumstances and the requirements of chosen enterprises [60].

Many regional and national initiatives continue to be based on the paradigm that more tourists are better. In 2005 the Savannah Way promotion commenced with the explicit aim of increasing drive tourism through the tropical savannas [21]. While information and signage infrastructure were put into place to guide tourists, no equivalent effort was made to consider unintended consequences or to put safeguards in place to minimise likely environmental and social impacts associated with increasing traffic and tourist numbers in remote regions. Consequently, northern Kimberley-style issues started to emerge in other regions such as the Roper River in the Northern Territory [61]. Similar issues associated with drive tourism also exist in Cape York [62]. In 2010, the Kimberley was afforded 'National Landscapes' status with the purpose of celebrating its environmental assets and promoting it internationally [22]. While this program in particular aims to foster indigenous participation in tourism, the fundamental externalities remain unaddressed and lack of relevant data continues to be a key limitation to informed decision making [11].

As Hall and Boyd ([10], pp. 9-10) explain the paradox of peripherality: "if the lure of remoteness [..] proves too great or is not adequately managed, destinations that are beginning to prosper economically may become overcrowded, environmentally degraded or subject to pressure (both external and internal) to modernise and change, thereby losing the very characteristics that encouraged their success."

Tourism planning and management require the availability of data relevant to the scale of planning and management. Most regions within Australia's tropical savannas form part of much larger destinations for the purpose of tourism promotion and data collection focuses at the destination level. The distinct tourist products and concerns of the smaller regions tend to be overshadowed by the major tourist areas within these larger destinations, and consequently the regions-even though they may attract visitors in their own right - are peripheral to the concerns of the larger destination. In addition, there might be conflicting objectives at the different levels of concern, whereby state and national organisations and agencies in particular seek to maximise tourist numbers for the benefit of national or state accounts while it might be in the best interest of remote destinations to query the tourism growth paradigm. Sophisticated tourism simulation models are unlikely to be available to remote savanna regions any time soon. Even accurate data of tourist numbers and impacts may not always be available to remote host populations to inform a discussion about tourism impacts and how to manage tourism 
for maximum net social benefit. This research highlights that resident surveys and expert consultations can provide a good indication of the situation and underlying issues.

The best spatial alignment of remote tourist regions is with local government areas, and, with the advent of regional natural resource management (NRM) in Australia in 2003 [63], regional NRM groups have assumed a stewardship function over environmental assets. Both levels of governance have some influence on tourism development. Both can invest in data collection - as the Northern Gulf Resource Management Group has done in relation to impact of fishing tourism [54] - and the generation of understanding by the host population of tourism. Both can contribute to information dissemination, promotion and lobbying or relevant decision makers.

Critical to the ability of local decision makers to better govern tourism development is the understanding that tourism net benefit is not only a function of tourist numbers but also tourist types. Also, by managing for tourist type, regions may be able to harness tourism systems relationships (Figure 1) to yield greater social net benefit and achieve a more equitable distribution of tourism-related economic benefits. This systems view explains that visitor attributes such as length of stay, spending patterns, activities and behaviours ultimately determine (i) whether tourism yields a net social benefit for a host destination and (ii) how benefits and costs are distributed across sectors of the economy and community [27]. Indeed, the Carpentaria Shire has in recent years implemented a number of the recommendations resulting from the research, which has in particular led to a diversification of tourist activities with the intention of shifting the mix of visitor types towards higher-spending lower-impact tourists and increasing indigenous participation in the sector. Data has not as yet been collected to verify and quantify the benefits of these measures.

The question of preferred style of tourism in a given destination and associated trade-offs is associated with political choices and based on value systems. To rise to the central challenge of ecologically sustainable development, options and associated trade-offs need to be explicit, based on systematic research, and accompanied by an ability to anticipate and monitor, and adaptively manage the system. This paper provides examples of empirical research which can support dialogue and underpin tourism planning and management - in an endeavour to (i) support decision makers in the peripheral areas of the tropical savannas of Australia to harness the potential of tourism as one driver of ecologically sustainable development and (ii) minimise the risk of nature-based tourism turning into a 'disaster' [6].

Ideally, research to support tourism planning and management goes beyond the scope of research afforded by the TSM-CRC. Quantitative destination-level simulation models have been developed for more prevalent nature-based tourist destinations including the Douglas Shire in north-east Queensland [64], for Tapestry region in south-west Western Australia [65] and the Ningaloo Coast in Western Australia [66]. These models are grounded in a similar systems view of tourism. Being simulation models, they are capable of quantifying likely influence of planning and management interventions - formulated as scenarios or levers — on the state of the natural assets, regional income from tourism and 'attractiveness' of various destinations. These models, in the words of Farrell and Twining-Ward [67], represent a 'reconceptualisation' of tourism systems in that they respond to conceptual-theoretical innovations including adaptive ecosystem cycle theory, scenario planning, simulation models, integrated assessment models, integrated landscape planning, regional information systems, and resilience analysis and management. 
It would appear that in the foreseeable future most remote regions within the tropical savannas of northern Australia will continue to present a nature-based tourist product. Remote communities' ability to derive livelihoods from tourism will depend on (i) whether they can safeguard the very environmental assets that attract tourists and the lifestyle assets that make tourists want to stay longer and (ii) their ability to diversify their tourist markets to shape their preferred style of tourism, but also to increase resilience [68], and (iii) their ability to compete with alternative tourist destinations nationally and internationally. It would also appear that there are cultural resources that are as yet untapped, which can provide an additional avenue for the indigenous population in many remote regions to economically and socially participate in tourism and the broader regional economy.

Based on the evidence presented in this paper, a number of conclusions can be drawn.

- Tourism growth in the tropical savannas has not been consistent with ESD principles as it has caused various social and environmental costs to remote regions and communities. The case studies in particular serve to illustrate that large indigenous populations may derive very little benefit from nature-based tourism.

- The assumption, persistent in many decision makers' minds, that more tourists are better needs to be queried and replaced by a consideration for the net social benefit from tourism for host populations. This transition in thinking requires an understanding of the remote destination, the tourists, and the relationships between tourists and the remote destination and host population. This understanding needs to underpin planning at the spatially relevant scale and systematic interventions in the form of public infrastructure, social and human capital, and institutions guiding tourist behaviour.

- The onus for sustainable tourism and regional development strategies in remote areas falls largely on local decision makers as these regions tend to be either peripheral to the concerns of state government agencies or tourism promotion agencies, or host population interests may be at odds with those of larger regions.

- Ongoing investment into tourism-related data collection across the tropical savannas is required to support the capacity of local governments, regional NRM groups and other agencies and organisations to plan for the future and safeguard natural assets.

- Lack of relevant and spatially appropriate data continues to pose major challenges to informed and appropriate decision making. The results of structured community consultations and surveys, of the type presented in this paper, can provide a truthful reflection of economic, social and environmental impacts in any given region. More structured data collection, governed by a tourism systems framework and at least of the scope undertaken by the TSM-CRC, is necessary to provide quantification of impact and a level of understanding of systems relationships, which can support ESD-compliant tourism development. 


\section{Acknowledgements}

I am grateful to two anonymous referees, Dean Carson and David Garnett for helpful comments. The Tropical Savannas Management Cooperative Research Centre funded the research, which provided the empirical foundation for this paper. Ron Ninnis (Charles Darwin University) kindly provided the map.

\section{References and Notes}

1. Ko, D.W.; Stewart, W.P. A structural equation model of residents' attitudes for tourism development. Tourism Manag. 2002, 23, 521-520.

2. Sofield, R.H.B.; Mactaggart, R. Tourism as a Tool for Sustainable Development in Transition Economies. In Proceedings of the GRM International October Conference, London, UK, 19 October 2005; Available online: http://www.grminternational.com/ (accessed on 15 May 2010).

3. Murphy, P.; Murphy, A. Regional tourism and its economic development links for small communities. In The Future of Australia's Country Towns; Rogers, M.F., Collins, Y.M.J., Eds.; Centre for Sustainable Regional Communities: Bendigo, Australia, 2001; pp. 162-171.

4. Sorensen, T.; Epps, R. The role of tourism in the economic transformation of the Central West Queensland economy. Aust. Geographer 2003, 24, 73-89.

5. Collins, G. Tourism in the Tropical Savannas. In The Future of Tropical Savannas: An Australian Perspective; Ash, A., Ed.; CSIRO Publishing: Collingwood, Australia, 1996; pp. 62-67.

6. Hall, C.M. Wasteland to World Heritage: Preserving Australia's Wilderness. Melbourne University Press: Carlton, AU, USA, 1992.

7. Preece, N.; van Oosterzee, P.; James, D. Two Way Track. Biodiversity Conservation and Ecotourism: An Investigation Of Linkages, Mutual Benefits and Future Opportunities; Study Commissioned by the Biodiversity Unit in the Environmental Strategies Directorate of the Commonwealth Department of the Environment, Sport and Territories, 1995; Available online: http://www.environment.gov.au/life/general_info/biodivser_5/two_con.html (accessed on 30 April 2003).

8. Australian Bureau of Statistics. Experimental Estimates of Aboriginal and Torres Strait Islander Australians, Jun 2006; Commonwealth of Australia: Canberra, Australia, 2008; Cat. No. 3238055001DO004_200606.

9. Benson, A.; Clifton, J. Assessing tourism's impacts using local communities' attitudes toward the environment. In Sustainable Tourism; Pineda, F.D., Brebbia, C.A., Eds.; WIT Press: Southampton, UK, 2004; pp. 3-12.

10. Hall, C.M.; Boyd, S. Nature-based tourism in peripheral areas: Introduction. In Nature-Based Tourism in Peripheral Areas: Development or Disaster?; Hall, C.M., Boyd, S., Eds.; Channel View Publications: North York, Canada, 2005; pp. 3-20.

11. Stoeckl, N.; Stanley, O.G. Land rich and data poor: Modeling requirements in Australia's Far North. Econ. Pap. 2005, 24, 230-248.

12. Smith, S.L.J. Challenges to tourism in industrialized nations. In Tourism, Development Growth: The Challenge for Sustainability; Wabah, S., Pigram, J.J.J., Eds; Routledge: Oxon, UK, 1997; pp. 147-163. 
13. Yuko Pty Ltd. The Impact of Tourism on the Gibb River Road: A Community Perspective; Tropical Savannas CRC: Darwin, Australia, 2003.

14. Greiner, R.; Larson, S. The Relationship between Landholders and Tour Operators. An Investigation of the Areas Adjoining the Gibb River Road in the North Kimberley; Tropical Savannas CRC: Darwin, Australia, 2004.

15. Greiner, R.; Mayocchi, C.; Larson, S.; Stoeckl, N.; Schweigert, R. Benefits and Costs of Tourism for Remote Communities: Case Study for the Carpentaria Shire in North-West Queensland; Tropical Savannas CRC: Darwin, Australia, 2004.

16. Greiner, R.; Larson, S.; Herr, A.; Pinger, P. Independent Travelers in the North Kimberley: Benefits, Impacts and Management Challenges; Tropical Savannas CRC: Darwin, Australia, 2005.

17. Burt, O.R.; Brewer, D. Estimation of net social benefits from outdoor recreation. Econometrica 1971, 39, 813-827.

18. Patterson, T.; Mapelli, F.; Tiezzi, E. Effects of tourism on net social benefits; defining optimal scale in the Merse watershed, Italy. Ecosyst. Sustain. Dev. 2003, IV, 397-406.

19. DEWHA. National Strategy for Ecologically Sustainable Development; Available online: http://www.environment.gov.au/esd/national/nsesd/strategy/intro.html\#Goal. (accessed on 15 May 2010).

20. Butler, R., Tourism-An evolutionary perspective. In Tourism and Sustainable Development: Monitoring, Planning, Management; Nelson, J.G., Butler R.W., Wall, G., Eds.; University of Waterloo Press: Waterloo, UK, 1993; pp. 27-43.

21. Savannah Way Ltd Homepage. http://www.savannahway.com.au/ (accessed on 1 May 2010).

22. Australian Government Gets behind Kimberley Tourism. States News Service, 12 April 2010.

23. Mill, R.C.; Morrison, A.M. The Tourism System, 4th ed.; Kendall/Hunt Publishing: Dubuque, IA, USA, 2002.

24. Stoeckl, N.; Greiner, R.; Mayocchi, C. The community impacts of different types of visitors: An empirical investigation of tourism in north-west Queensland. Tourism Manage. 2006, 27, 97-112.

25. Ko, J. Assessing progress of tourism sustainability. Ann. Tourism Res. 2001, 28, 817-820.

26. Dwyer, L.; Forsyth, P.; Spur, R. Evaluating tourism's economic effects: New and old approaches. Tourism Manage. 2004, 25, 307-317.

27. Leiper, N. Tourist attraction systems. Ann. Tourism Res. 1990, 17, 367-384.

28. Gunn, C.A. Tourism Planning: Basics, Concepts, Cases, 3rd ed.; Taylor and Francis: Washington, DC, USA, 1994.

29. Smith, S.L.J. The tourism product. Ann. Tourism Res. 1994, 21, 582-595.

30. Butler, R.W. The concept of a tourist area cycle of evolution: Implications for management of resources. Can. Geogr. 1980, 24, 5-12.

31. Aledo, A.; Mazón, T. Impact of residential tourism and the destination life cycle theory. In Sustainable Tourism; Pineda, F.D., Brebbia C.A., Eds.; WIT Press: Southampton, UK, 2004; pp. 25-36. 
32. Murphy, L. Understanding the social networks of backpacker travelers: A social situation analysis approach. In Tourism and Hospitality Research: Australian and International Perspectives: Working Papers from the Australian Tourism and Hospitality Research Conference; Prosser, G., Ed.; Bureau of Tourism Research: Canberra, Australia, 1996; p. 63.

33. Pearce, P.L.; Moscardo, F.; Ross, G.F. Tourism Community Relationships; Elsevier: Oxford, UK, 1996.

34. Tothill, J.C.; Gillies, C. The Pasture Lands of Northern Australia; Tropical Grasslands Society of Australia: Brisbane, Australia, 1992; Tropical Grassland Society of Australia Occasional Publication No. 5.

35. Bortolussi, G.; Mcivor, J.G.; Hodgkinson, J.J.; Coffey, S.G.; Holmes, C.R. The northern Australian beef industry, a snapshot. 1. Regional enterprise activity and structure. Aust. J. Exp. Agr. 2005, 45, 1057-1073.

36. Holmes, J. Impulses towards a multifunctional transition in rural Australia: Gaps in the research agenda. J. Rural Stud. 2006, 22, 142-160.

37. BITRE. Northern Australia Statistical Compendium 2009; Australian Government Department of Infrastructure, Transport, Regional Development and Local Government: Canberra, Australia, 2009.

38. DEEWR. Regional Employment Profiles: Industry and Occupation; Australian Government Department of Education, Employment and Workplace Relations: Canberra, Australia; 2009; Available online: http://www.workplace.gov.au/workplace/Publications/ResearchStats/Labour MarketAnalysis/RegionalEmploymentProfileIndustryOccupation/ (accessed on 30 November 2009).

39. Brown, F.; Hall, D. Introduction: The paradox of peripherality. In Case Studies of Tourism in Peripheral Areas, Proceedings of an International Seminar on Bornholm, September 1997; Brown, F., Hall, D., Eds.; Research Centre of Bornholm: Nexø, Denmark, 1999; pp. 7-14.

40. OESR. Carpentaria Shire, 2010; Available online: http://statistics.oesr.qld.gov.au/qld-regionalprofiles (accessed on 11 May 2010).

41. Shire of Derby-West Kimberley, 2010; Available online: http://www.sdwk.wa.gov.au (accessed on 11 May 2010).

42. Larson, S.; Herr, A. Sustainable tourism development in remote regions? Questions arising from research in the North Kimberley, Australia. Reg. Environ. Chang. 2008, 8, 1-13.

43. Hall, C.M.; Page, S.J. The Geography of Tourism and Recreation, 2nd ed.; Routledge: London, UK; New York, NY, USA, 2002.

44. Kimberley Australia Travel Guide, 2010; Available online: http://www.kimberleyaustralia.com/ gibb-river-road.html (accessed on 10 May 2010).

45. North Australia Fish Finder; North Australia Fish Finder: Darwin, Australia, 2009.

46. Butler, R.; Hinch, T. Indigenous tourism: A common ground for discussion. In Tourism and Indigenous Peoples, 1st ed.; Butler, R., Hinch, T., Eds; International Thomson Business Press: London, UK; Boston, MA, USA, 1996; pp. 3-21.

47. Salant, P.; Dillman, D.A. How to Conduct Your Own Survey; John Wiley \& Sons: Hoboken, NJ, USA, 1994. 
48. Tosum, C. Host perceptions of impacts: A comparative tourism study. Ann. Tourism Res. 2002, 29, 231-253.

49. King, B.; Pizam, A.; Milman, A. Social impacts of tourism: Host perceptions. Ann. Tourism Res. 1993, 20, 650-665.

50 . Milman, A.; Piam, A. Social impacts of tourism on central Florida. Ann. Tourism Res. 1988, 15, 191-204.

51. Namsfeld, Y. Group-differentiated perceptions of social impacts related to tourism development. Prof. Geogr. 1992, 44, 377-392.

52. Van Doorn, M.W. A critical assessment of socio-cultural impact studies of tourism in the Third World. In Towards Appropriate Tourism: The Case of Developing Countries; Singh, T.V., Theuns, H.L., Go, F.M., Eds.; Peter Lang: Frankfurt/Main, Germany, 1989; pp. 71-91.

53. Liu, J.C.; Var, T. Resident attitudes toward tourism impacts in Hawaii. Ann. Tourism Res. 1986, 13, 402-427.

54. Greiner, R.; Patterson, L. Towards Sustainable Management of Recreational Fishing in The Gulf of Carpentaria: Investigation into Recreational Fishing in Karumba; Report to the Northern Gulf Resource Management Group; River Consulting: Townsville, Australia, 2007.

55. Greiner, R.; Gregg, D. Considering recreational catch and harvest in fisheries management at the bio-regional scale. Fisheries Manag. Ecol. 2010, in press.

56. Smith, A.J.; Scherrer, P.; Dowling, R. Impacts on Aboriginal spirituality and culture from tourism in the coastal waterways of the Kimberley region, North West Australia. J. Ecotour. 2009, 8, 82-98.

57. Collin, J.H. Marine Tourism in the Kimberley Region of Western Australia. Geogr. Res. 2008, 46, 111-117.

58. Irvinek, W.; Anderson, A.R. Small tourist firms in rural areas: agility, vulnerability and survival in the face of crisis. Int. J. Entrep. Behav. Res. 2004, 10, 229-246.

59. Jawoyn Association Aboriginal Corporation. Achievements; Available online: http://www. jawoyn.org/achievements.htm (accessed on 15 June 2010).

60. Altman, J.; Finalyson, J. Aborigines, tourism and sustainable development. J. Tourism Stud. 2003, 14, 78-91.

61. Chalmers, J. Roper River Landcare Group, Mataranka, Australia. Personal communication, 2005.

62. Tourism Queensland. Cape York Tourism Market Assessment \& Potential; Available online: http://www.tq.com.au/fms/tq_corporate/research/destinationsresearch/tropical_north_qld/cape_yo rk_visitor_research.pdf (accessed on 3 June 2010).

63. Pannell, D.J.; Ridley, A.; Seymour, E.; Regan, P.; Gale, G. Regional Natural Resource Management Arrangements for Australian States: Structures, Legislation And Relationships to Government Agencies, Version 3.2, 2008; Available online: http://cyllene.uwa.edu.au/ $\sim$ dpannell/cmbs3.pdf (accessed on 15 June 2010).

64. Walker, P.A.; Greiner, R.; McDonald, D.; Lyne, V. The Tourism Futures Simulator: A Systems Thinking Approach. Environ. Modell. Softw. 1999, 15, 59-67.

65 Walker, P.A.; Lee, D.; Goddard, R.; Kelly, G.; Pedersen, J. Regional Tourism Modeling: The South West Tapestry; Sustainable Tourism CRC: Gold Coast, Australia, 2005. 
66. Jones, T.; Wood, D.; Hughes, M.; Pham, T.; Pamdubi, D.; Spurr, R.; Dwyer, L.; Deery, M.; Fredline, L. Tourism Destination Modeling: Building a Sustainable Planning Tool for Australian Tourism Destinations; Sustainable Tourism CRC: Gold Coast, Australia. 2010.

67. Farrell, B.H.; Twining-Ward, L. Reconceptualizing tourism. Ann. Tourism Res. 2004, 31, 274-295.

68. Carson, D.B.; Taylor, A.J. Sustaining four wheel drive tourism in desert Australia: Exploring the evidence from a demand perspective. Rangel. J. 2008, 30, 77-83.

(C) 2010 by the authors; licensee MDPI, Basel, Switzerland. This article is an Open Access article distributed under the terms and conditions of the Creative Commons Attribution license (http://creativecommons.org/licenses/by/3.0/). 